\title{
Experiment of Partial Replacement of Egg Shell Powder and Coconut Fibre in Concrete
}

\author{
Sathvik S, Edwin. A, Anmol Basnett, Prerna Sharma, Jemimah carmicheal
}

\begin{abstract}
ABSTARCT: India is in fifth position in the world annual egg production. About 1.61 million tons of egg shells are being waste annually by disposing it as a landfill, which attracts vermin due to attached membrane and causes problems to human health and environment.It is scientifically known that the eggshell is mainly composed of compounds of calcium. Calcium carbonate, $\left(\mathrm{CaCO}_{3}\right)$, is the major composition of the eggshell, accounting for 93.70\% of the total composition of the eggshell. Similarly, calcium carbonate $\left(\mathrm{CaCO}_{3}\right)$, is the primary raw material in the production of cement. The produced OPC is composed of four main Calcium compounds in the forms of di calcium silicates, $\left(C_{2} S\right)$, tri calcium silicate, $\left(C_{3} S\right)$, tri calcium aluminate, $\left(C_{3} A\right)$, and tetra-calcium aluminoferite, $\left(C_{4} A F\right)$. It is, therefore, indicated that cement and eggshells have the same primary composition in calcium compounds.
\end{abstract}

Calcium rich egg shell is a poultry waste with chemical composition nearly same as that of limestone. Use of eggshell waste instead of natural lime to replace cement in concrete can have benefits like minimizing use of cement, conserving natural lime and utilizing waste material. Eggshell waste can be used as fertilizer, animal feed ingredients and other such uses.

Keywords: Eggshell, Calcium carbonate, calcium silicates, tri calcium silicate, tetra-calcium aluminoferite.

\section{INTRODUCTION}

Concrete is the most commonly used building material. It has the advantage of being formed into any desired shape most conveniently. It is an artificial stone obtained by mixing aggregates, cement and water allowing this product to cure for hardening.The word concrete came from Latin term CONCRETEUS, which means to grow Strength and some other properties of concrete depend on hydration products, which continue to form for severalyears.

The fine and coarse aggregates in a concrete mix are the inert, or inactive, ingredients. Cement and water are the active ingredients. The inert ingredients and the cement are first thoroughly mixed together. As soon as the water is added, a chemical reaction begins between the water and the cement. The reaction, called hydration, causes the concrete to harden. The hardening process occurs through hydration of the cement by the water, not by drying out of the mix.

Revised Manuscript Received on April 12, 2019.

Sathvik S, Dept. of Civil Engineering, SRM Institute of Science \& Technology, Chennai, T.N, India.

Edwin. A, Dept. of Civil Engineering, SRM Institute of Science \& Technology (edwinraj91@ gmail.com), 9840696191 Chennai, T.N, India.

Anmol Basnett, Dept. of Civil Engineering, Karunya Institute of Technology \& Science Coimbatore, T.N, India.

Prerna Sharma, Dept. of Civil Engineering, Karunya Institute of Technology \& Science, Coimbatore, T.N, India.

Jemimah carmicheal, Dept. of Civil Engineering, Karunya Institute of Technology \& Science, Coimbatore, T.N, India.
Instead of being dried out, concrete must be kept as moist as possible during the initial hydration process. Drying out causes a drop in water content below that required for satisfactory hydration of the cement. The fact that the hardening process does not result from drying out is clearly shown by the fact that concrete hardens just as well underwater as it does inair.

Its essential ingredients are cement and water which react with each other chemically, to form another material having the useful strength. The strength of concrete depends upon the quality of its ingredients, their relative quantities and the manner in which they are mixed, compacted and cured. It is possible to produce concrete of different specifications for various purposes by suitably adjusting the proportion of cement.Concrete is a composite material that consists essentially of a bonding medium within which are embedded particles of fragments of aggregates. In hydraulic cement concrete, the binder is formed from a mixture of cement and water.

Cement is a finely powdered material, which by itself is not a binder, develops binding properties as a result of hydration. Cement is called hydraulic when the hydraulic products are stable in aqueous environment (water resistance). The term sand is commonly used to fine aggregates resulting from disintegration and absorption process of sand stone. Fine aggregated refers to particle size smaller than $4.75 \mathrm{~mm}$ and larger the $75 \mathrm{micron}$. Crushed stone is the product resulting from industrial crushing of rocks, boulde.

\section{MATERIALS AND METHODOLOGY}

\section{COARSEAGGREGATE}

The Maximum size of aggregate affects the workability and strength of concrete. It also influences the water demand for getting a certain workability and fine aggregate content required for achieving a cohesive mix. In other words for the same workability, $40 \mathrm{~mm}$ down aggregate will have lower water/cement ratio, thus higher strength when compared to $20 \mathrm{~mm}$ down aggregate. Because of its lower water demand, advantage of higher maximum size of coarse aggregate can be taken to lower the cement consumption. 


\section{FINEAGGREGATE}

Fine aggregates make up the bulk of a concrete mixture. Sand, natural gravel and crushed stone are used mainly for this purpose. Recycled aggregates (from construction, demolition, and excavation waste) are increasingly used as partial replacements of natural aggregates, while a number of manufactured aggregates, including air-cooled blast furnace slag and bottom ash are also permitted.

\section{CEMENT}

Portland cement is the most common type of cement in general usage. It is a basic ingredient of concrete, mortar and plaster. English masonry worker Joseph Asp din patented Portland cement in 1824. It was named because of the similarity of its color to Portland limestone, quarried from the English Isle of Portland and used extensively in London architecture. It consists of a mixture of oxides of calcium, silicon and aluminum. Portland cement and similar materials are made by heating limestone (a source of calcium) with clay and grinding this product (called clinker) with a source of sulfate (most commonlygypsum).

\section{EGGSHELL POWDER(ESP)}

India is in fifth position in the world annual egg production. About 1.61 million tons of egg shells are being waste annually by disposing it as a landfill, which attracts vermin due to attached membrane and causes problems to human health and environment.

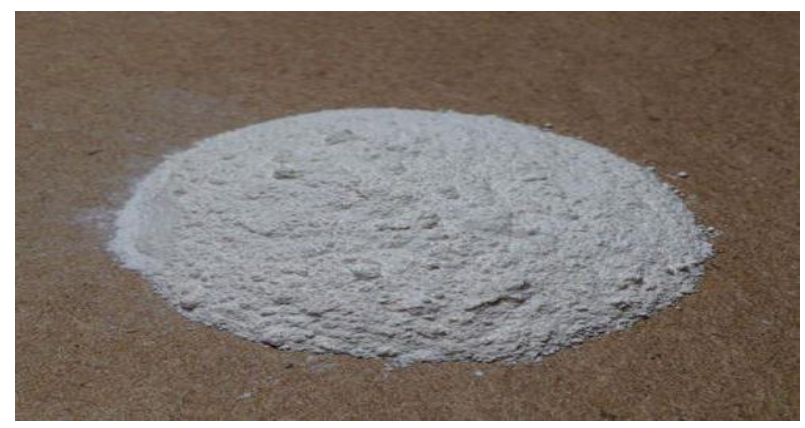

Fig 1 Egg Shell powder

\section{COCONUTCOIRS $(C C)$ :}

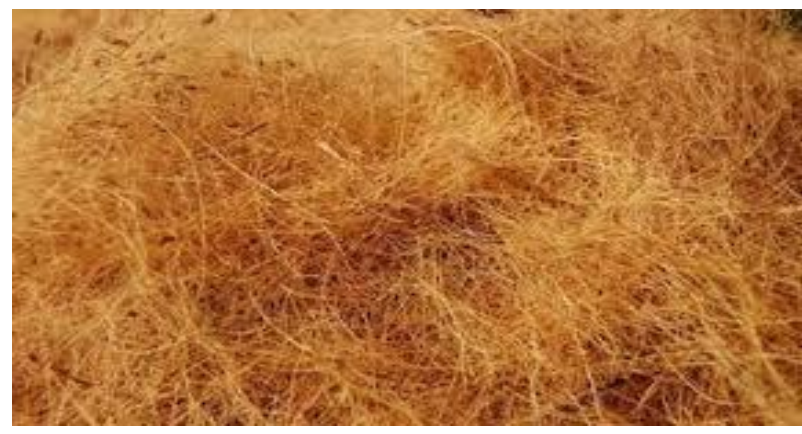

Fig 2 Coconut coir

Natural fibres are those fibre which are pollution free, environment friendly and does not have any bad effect on climate. Every year there is ample amount of wastages of natural fibre. If these natural fibres used as a construction material it could save the bio-reserves. They acts as green construction material. Amongst all natural fibres, CF is the fibre which has the better physical and chemical property also it is renewable, cheap, resistant to thermal conductivity, more durable, highest toughness, most ductile then the other natural fibre, it is capable of taking strain four time more than other fibres. Hence, CF is a best material.

\section{TESTING OF BASICMATERIALS}

\section{TESTS ONCEMENT}

53 Grade cement confirming to IS: 12269-2013 was used. The tests were carried out according to the codal provisions. By compatibility test we have selected Coromandel King 53 OPC cement for further studies.

Table 1 Cement test result

\begin{tabular}{|c|c|c|c|}
\hline $\begin{array}{c}\text { SL. } \\
\text { No. }\end{array}$ & Test & Results & $\begin{array}{c}\text { Requirements as } \\
\text { per IS:12269-2013 }\end{array}$ \\
\hline 1. & $\begin{array}{c}\text { Normal } \\
\text { Consistency }\end{array}$ & $31 \%$ & Not Specified \\
\hline 2. & $\begin{array}{c}\text { Initial Setting } \\
\text { Time }\end{array}$ & $45 \mathrm{~min}$ & $\begin{array}{c}\text { Shall not be less than } \\
30 \text { minutes }\end{array}$ \\
\hline 3. & $\begin{array}{c}\text { Final Setting } \\
\text { Time }\end{array}$ & $325 \mathrm{~min}$ & $\begin{array}{c}\text { Shall not be more } \\
\text { than } 600 \text { minutes }\end{array}$ \\
\hline 4. & $\begin{array}{c}\text { Specific } \\
\text { Gravity }\end{array}$ & 3.22 & Not Specified \\
\hline 5. & Fineness & $1.8 \%$ & $\begin{array}{c}\text { Should be less than } \\
10 \% \text { of its weight }\end{array}$ \\
\hline
\end{tabular}

\section{TEST ON EGG SHELL POWDER(ESP)}

\section{RESULTS}

\section{$\mathrm{M}_{30}$ Grade Conventional Concrete $(0.5$ w/cratio)}

Average Compressive strength of Conventionalconcrete:

The concrete cubes of M30 grade $(0.5 \mathrm{w} / \mathrm{c}$ ratio) were prepared by using laboratory tap water and curing carried out by using laboratory tap water. The compressive strength test is carried out on each specimen and the results are depicted in tablebelow:

Table 2 Average Compressive strength of Conventional concrete

\begin{tabular}{|c|c|c|c|c|c|}
\hline \multirow{3}{*}{ W/c } & \multirow{2}{*}{ ESP } & \multicolumn{2}{|c|}{$\begin{array}{c}\text { COMPRESSIVE STRENGTH } \\
\text { OF CONCRETE AT }\end{array}$} & \multirow{2}{*}{ Weight } \\
& & DIFFERENT CURING AGES & \\
\cline { 3 - 5 } & & 7 DAYS & $\begin{array}{c}14 \\
\text { DAYS }\end{array}$ & $\begin{array}{c}28 \\
\text { DAYS }\end{array}$ & \\
\hline \multirow{4}{*}{0.5} & $5 \%$ & 16.87 & 34.14 & 37.29 & 7.98 \\
\cline { 2 - 6 } & $10 \%$ & 14.65 & 27.66 & 31.45 & 7.96 \\
\cline { 2 - 5 } & $15 \%$ & 12.49 & 23.75 & 27.495 & 7.99 \\
\cline { 2 - 5 } & $20 \%$ & 10.5 & 14.41 & 21.64 & 8.12 \\
\hline
\end{tabular}

Average Tensile strength of Conventionalconcrete:

The concrete cylinders of M30 grade $(0.5 \mathrm{w} / \mathrm{c}$ ratio) were prepared by using laboratory tap water and curing carried out by using laboratory tap water. The split tensile strength test is carried out on each specimen and the results are depicted in table below: 
Table 3 Average Tensile strength of Conventional concrete

\begin{tabular}{|c|c|c|c|}
\hline W/c & $\begin{array}{c}\text { Curing Age } \\
\text { (days) }\end{array}$ & $\begin{array}{c}\text { Weight of } \\
\text { cube (Kg) }\end{array}$ & $\begin{array}{c}\text { Average } \\
\text { compressive } \\
\text { strength(N/mm }\end{array}$ \\
\hline \multirow{2}{*}{0.50} & 7 & 8.006 & 19.23 \\
\cline { 2 - 4 } & 14 & 8.007 & 35.23 \\
\cline { 2 - 4 } & 28 & 8.006 & 39.86 \\
\hline
\end{tabular}

M30 Grade Replaced with Egg Shell Powder (0.5 w/cratio)

Average Compressive strength for Egg shell powder replacement

The concrete cubes of M30 grade $(0.5 \mathrm{w} / \mathrm{c}$ ratio) were prepared by using laboratory tap water and curing carried out by using laboratory tap water. The compressive strength test is carried out on each specimen and the results are depicted in table below:

Table 4 Average Compressive strength for Egg shell powder replacement

\begin{tabular}{|c|c|c|c|}
\hline W/c & $\begin{array}{c}\text { Curing } \\
\text { Age (days) }\end{array}$ & $\begin{array}{c}\text { Weight of } \\
\text { cube (Kg) }\end{array}$ & $\begin{array}{c}\text { Average compressive } \\
\text { strength(N/. } \mathbf{m m} \mathbf{2}^{\mathbf{}} \text { ) }\end{array}$ \\
\hline \multirow{3}{*}{0.50} & 7 & 12.43 & 1.73 \\
\cline { 2 - 4 } & 14 & 12.32 & 2.23 \\
\cline { 2 - 4 } & 28 & 12.12 & 2.48 \\
\hline
\end{tabular}

Fig 3 Average Compressive strength for Egg shell powder replacement

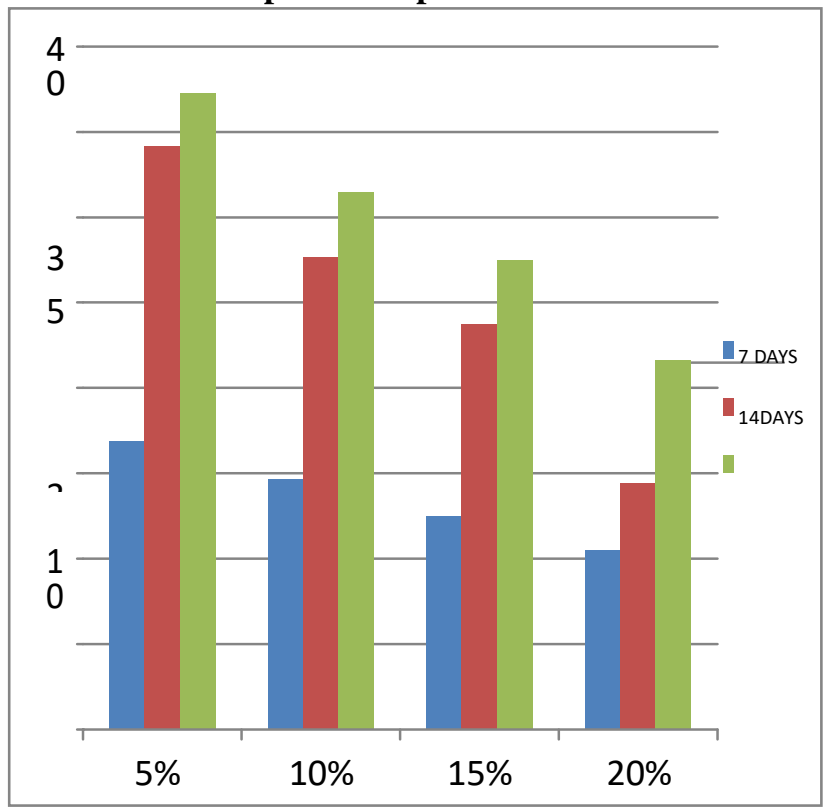

Average Split Tensile strength for Egg Shell powder replacement

The concrete cylinders of M30 grade $(0.5 \mathrm{w} / \mathrm{c}$ ratio) were prepared by using laboratory tap water and curing carried out by using laboratory tap water. The split tensile strength test is carried out on each specimen and the results are depicted in table below:

\begin{tabular}{|c|c|c|c|c|c|}
\hline \multirow[t]{2}{*}{$\begin{array}{c}\text { W/ } \\
\mathrm{c}\end{array}$} & \multirow[t]{2}{*}{$\begin{array}{c}\mathrm{ES} \\
\mathrm{P}\end{array}$} & \multicolumn{3}{|c|}{$\begin{array}{c}\text { SPLIT TENSILE STRENGTH OF } \\
\text { CONCRETE ATDIFFERENT CURING } \\
\text { AGES }\end{array}$} & \multirow[t]{2}{*}{$\begin{array}{l}\text { Wei } \\
\text { ght }\end{array}$} \\
\hline & & 7 DAYS & 14 DAYS & 28 DAYS & \\
\hline \multirow{4}{*}{0.5} & $5 \%$ & 1.62 & 2.03 & 2.12 & $\begin{array}{c}12.5 \\
6\end{array}$ \\
\hline & $\begin{array}{l}10 \\
\%\end{array}$ & 1.51 & 1.62 & 1.67 & $\begin{array}{c}12.4 \\
8\end{array}$ \\
\hline & $\begin{array}{l}15 \\
\%\end{array}$ & 1.31 & 1.41 & 1.49 & $\begin{array}{c}12.6 \\
5\end{array}$ \\
\hline & \begin{tabular}{|l|}
20 \\
$\%$
\end{tabular} & 1.13 & 1.27 & 1.3 & $\begin{array}{c}12.5 \\
9\end{array}$ \\
\hline
\end{tabular}

Table 5 Average Split Tensile strength for Egg Shell powder replacement

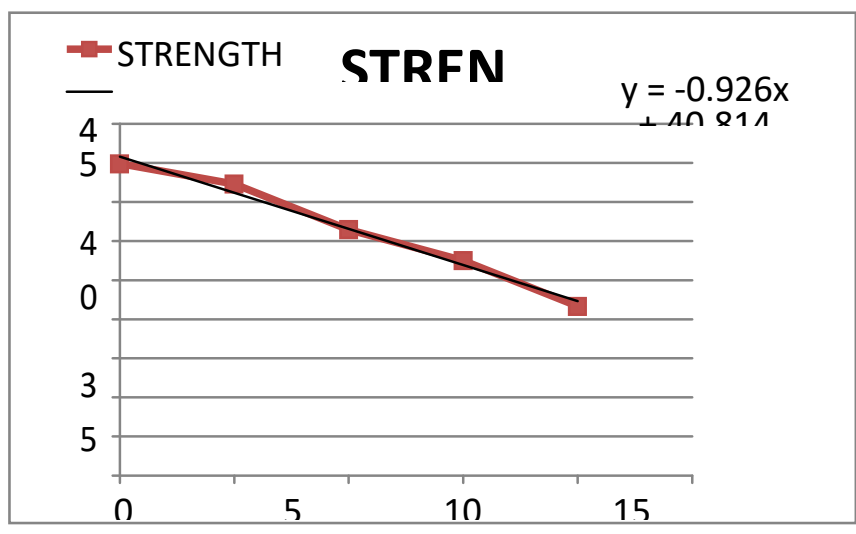

Fig 4 Average Split Tensile strength for Egg Shell powder replacement

REGRESSIONANALYSIS \& RESULTS

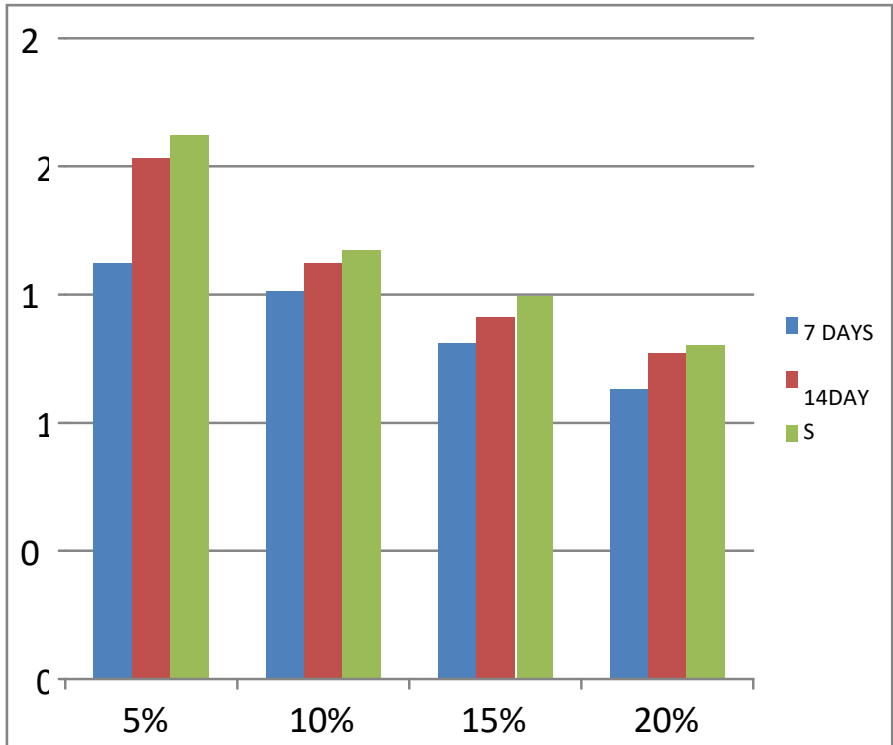

Fig 5 Regression Analysis X= 2.77\%

M30 Grade Replaced with Egg Shell Powder and Coconut $\operatorname{coir}(0.5 w / c)$

In statistical modeling, regression analysis is a set of statistical processesforestimating the relationships among variables. It includes many techniques for modeling and analyzing several variables, when the focus is on the 
relationship between a dependentvariable and one or more independent variables. More specifically, regression analysis helps one understand how the typical value of the dependent variable changes when any one of the independent variables is varied, while the other independent variables are held fixed.

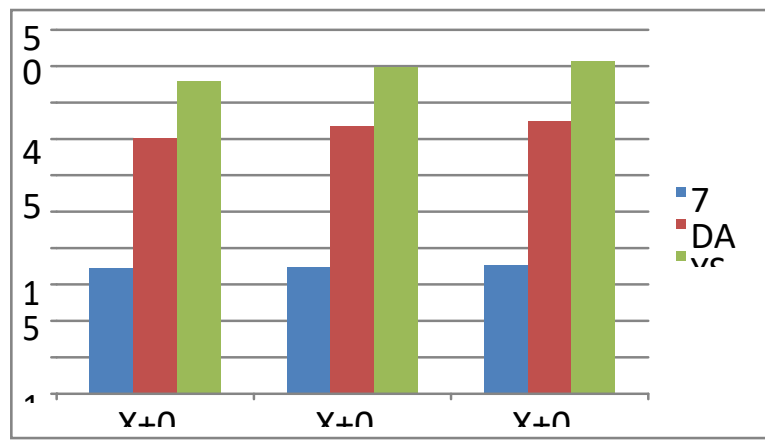

Fig 6 Average Compressive strength for Egg Shell powder and coconut coir

Average Compressive strength for Egg Shell powder and coconut coir

The concrete cubes of M30 grade ( $0.5 \mathrm{w} / \mathrm{c}$ ratio) were prepared by using laboratory tap water and curing carried out by using laboratory tap water. The compressive strength test is carried out on each specimen and the results are depicted in table below:

Table 6 Average Compressive strength for Egg Shell powder and coconut

\begin{tabular}{|c|c|c|c|c|c|}
\hline \multirow[t]{2}{*}{$\mathrm{W} / \mathrm{c}$} & \multirow{2}{*}{$\begin{array}{c}\text { ESP } \\
3.43 \%+ \\
\mathrm{CC}\end{array}$} & \multicolumn{3}{|c|}{$\begin{array}{l}\text { COMPRESSIVE STRENGTH OF } \\
\text { CONCRETE } \\
\text { AT DIFFERENT CURING AGES }\end{array}$} & \multirow[t]{2}{*}{ Weight } \\
\hline & & 7 DAYS & 14 DAYS & 28 DAYS & \\
\hline \multirow{3}{*}{0.5} & $0.2 \%$ & 17.23 & 35.09 & 42.85 & 7.85 \\
\hline & $0.4 \%$ & 17.39 & 36.74 & 44.88 & 8.09 \\
\hline & $0.6 \%$ & 17.68 & 37.36 & 45.59 & 7.65 \\
\hline
\end{tabular}

The concrete cylinders of M30 grade $(0.5 \mathrm{w} / \mathrm{c}$ ratio) were prepared by using laboratory tap water and curing carried out by using laboratory tap water. The split tensile strength test is carried out on each specimen and the results are depicted in table below:

Table 7 Average Split Tensile strength for Egg Shell powder and coconut coir

\begin{tabular}{|c|c|c|c|c|c|}
\hline \multirow{3}{*}{ W/c } & $\begin{array}{c}\text { ESP 2.77\% } \\
+ \text { CC }\end{array}$ & \multicolumn{3}{|c|}{$\begin{array}{c}\text { SPLIT TENSILE } \\
\text { STRENGTH OF } \\
\text { CONCRETE }\end{array}$} & \multirow{2}{*}{ Weight } \\
& & AT DIFFERENT CURING & \\
& & \multicolumn{3}{|c|}{ AGES } & \\
\cline { 3 - 6 } & & 7 DAYS & $\begin{array}{c}14 \\
\text { DAYS }\end{array}$ & $\begin{array}{c}28 \\
\text { DAYS }\end{array}$ \\
\hline \multirow{4}{*}{0.5} & $0.2 \%$ & 2.31 & 2.37 & 2.7 & 12.55 \\
\cline { 2 - 6 } & $0.4 \%$ & 2.44 & 2.46 & 2.81 & 12.76 \\
\cline { 2 - 5 } & $0.6 \%$ & 2.56 & 2.56 & 2.88 & 12.45 \\
\hline
\end{tabular}

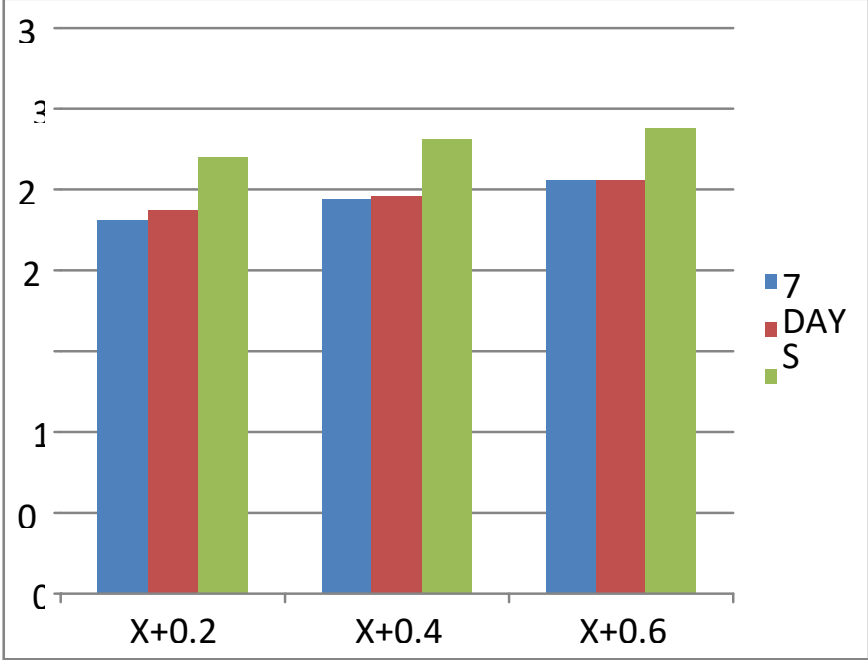

Fig 7 Average Split Tensile strength for Egg Shell powder and coconut coir

\section{CONCLUSION}

- It was observed that with the increase in Egg shell powder content, the workability of the concrete reduces, however it is found that compressive strength of $5 \%$ and $10 \%$ egg shell powder was comparatively lesser than that of the conventional $\mathrm{M}_{30}$ concrete inpractical.

- It is seen from the above results that beyond $10 \%$ of eggshell powder addition there is drastic decrease in compressive and split tensile strength than the conventional concrete.

- Linear Regressive analysis was done on Egg shell powder concrete and the following equation wasobtained, $\mathrm{Y}=-0.926 \mathrm{X}+40.814$

- From the above equation, we get $2.77 \%$ of egg shell powder is optimum.

- It is found that $2.77 \% \mathrm{ESP}$ and $0.6 \% \mathrm{CC}$ gave greater compressive and Split tensile strength than conventional M30 concrete.

- It was observed that Egg Shell Powder forms a viable option as a replacement for cement in concrete, and even coconut coirs be added in concrete to improve its properties.

\section{FUTURE SCOPE}

- Future research can be made with the addition of super plasticizers such that the workability of the concreteincreases.

- Future research can be made with an increased percentage of egg shell powder being added to concrete for higher grades of concrete so as to test itsproperties.

- Future research can be carried out to see other calcium based elements as a option for replacement of cement in concrete and test itsproperties. 


\section{REFERENCES}

1. AnandBabu, Ramprasanth A, Shanmugavadivu V," EXPERIMENTAL INVESTIGATION ON PARTIAL REPLACEMENT OF EGGSHELL POWDER IN CONVENTIONAL CONCRETE" International Journal of ChemTech Research Vol.10 No.8, pp 453-457,2017

2. Bandhavya G, Sandeep, Bindhushree G, “ AN EXPERIMENTAL STUDY ON PARTIAL REPLACEMENT OF CEMENT WITH EGG SHELL POWDER IN CONCRETE" International Research Journal of Engineering and Technology (IRJET)- June-2017.

3. Dhanalakshmi M, DrSowmya N J, DrChandrashekar A “A COMPARITIVE STUDY ON EGG SHELL CONCRETE WITH PARTIAL REPLACEMENT OF CEMENTBY FLY ASH" International Journal for Research in Applied Science \& Engineering Technology (IJRASET) Volume 3, Special IssueI1, June2015

4. Gowsika.D, Sarankokila.S, Sargunan.K "EXPERIMENTAL INVESTIGATION OF EGG SHELL POWDER AS PARTIAL REPLACEMENT WITH CEMENT IN CONCRETE" International Journal of Engineering Trends and Technology (IJETT) - Volume 14 Number 2 - Aug2014.

5. Karthick.J, IIR.Jeyanthi, IIIM.Petchiyammal, "EXPERIMENTAL STUDY ONUSAGE OF EGG SHELL AS PARTIAL REPLACEMENT FOR SAND IN CONCRETE" International Journal of Advanced Research in Education Technology (IJARET) Vol. 1, Issue 1 (July Sept.2014)

6. Mohamed Ansari M, Dinesh Kumar M, Milan Charles J, Dr.Vani G,"REPLACEMENT OF CEMENT USING EGGSHELL POWDER" SSRG International Journal of Civil Engineering (SSRG-IJCE) - volume 3 Issue 3-March2016.

7. Parbhane.D.M, Shinde.S.B," STRENGTH PROPERTIES OF COIR FIBER CONCRETE", INTERNATIONAL JOURNAL OF CIVIL ENGINEERINGAND TECHNOLOGY (IJCIET) Volume 5, Issue 2, February(2014)

8. Shreeshail.B.H, JaydeepChougale, Dhanraj Pimple, Amar kulkarni, "EFFECTS OF COCONUT FIBERS ON THE PROPERTIES OF CONCRETE” IJRET: International Journal of Research in Engineering and Technology-2014. 